\title{
Den konstitutionelle vending i Danmark og Europa og dens amerikanske rodder
}

\begin{abstract}
Dansk demokrati er ved at ændre sig fra demokrati uden konstitutionalisme - dvs. et rent parlamentarisk demokrati - til et demokrati med konstitutionalisme. Vi orienterer os i stigende grad mod retlige fora og gør brug af en rettighedsdiskurs, når vi skal løse konflikter. Om end der her synes at være tale om tendenser, der også kan iagttages hos vore europæiske naboer, og som mange umiddelbart tilskriver EU og det europæiske samarbejde, er den oprindelige inspirationskilde USA. Vi er ikke ved at fă "amerikanske tilstande", men i forsøget på at bearbejde de problemer, som naturligt opstår, fordi vi bliver mere multikulturelle og globalt orienterede, synes vi at vælge løsningsmodeller, der er velkendte fra en amerikansk kontekst.
\end{abstract}

"... democracy and human rights do not necessarily advance hand in hand. In order to reconcile democracy and human rights, Western policy will have to put more emphasis not on democracy alone but on constitutionalism, the entrenchment of a balance of powers, judicial review of executive decisions, and enforceable minority rights guarantees. Democracy without constitutionalism is simply ethnic majority tyranny" (Michael Ignatieff, 2001: 30).

Siden Højesteret i februar 1999 underkendte Tvindloven, har der som bekendt været nogen ved siden af, ja endda over Folketinget. Flere jurister har givet udtryk for, at Tvinddommen ikke nødvendigvis kan tages som et udtryk for en ny og mere aktiv Højesteret; den var måske "kun" et udtryk for, at Højesteret gav Folketinget en hårdt tiltrængt påmindelse om grundlovens magtfordelingslære. Dette er imidlertid, som Gorm Toftegaard Nielsen udtrykker det, "ikke til hinder for en diskussion af, om domstolene på andre områder har og bør have en styrket rolle i magtspillet eller en øget retsskabende funktion" (Nielsen, 2001: 155). Samtidig er det ikke hverdagskost i Danmark, at dommere og andre jurister offentligt kritiserer medlemmer af Folketinget og deres arbejde. Dette skete ikke desto mindre i forsommeren 2003 i forbindelse med vedtagelsen af det af justitsminister Lene Espersen fremsatte "Forslag til ændring af straffeloven og retsplejeloven (Bekæmpelse af rockerkriminalitet og anden organiseret kriminalitet)". Rockerloven, som den nye lov hurtigt blev kaldt, åbner for politiets brug af civile agenter, der skal beskyttes af anonymitet, ligesom den giver politiet større mulighed for rumog telefonaflytning. Det retspolitisk vigtigste er dog, at loven vil kunne forhindre dommere og forsvarere i at få fuld indsigt i efterforskningsmaterialet.

Imod sædvane blev lovforslaget fremsat på baggrund af en snævert sammensat arbejdsgruppe bestående af repræsentanter for politi og anklagemyndighed. Hverken dommere, advokater, universitetsjurister eller repræsentanter for andre relevante interesseorganisationer blev inddraget $\mathrm{i}$ det lovforberedende arbejde. Såvel lovens indhold som dens tilblivelsesproces førte til en række væsentlige 
kommentarer fra forskellige jurister. "Er befolkningen indstillet på at slække på retssikkerheden i kampen mod rockerkriminalitet?", spurgte professor Eva Smith i en kronik i Politiken (Smith, 2003). Landsdommer Holger Kallehauge var så bekymret over retssikkerheden i regeringens rockerpakke, at han direkte truede med at sabotere politikernes ønske om at lade politiet bruge civile agenter. "Det er ikke en retlig revolution, jeg vil gøre mig til talsmand for, men jeg er dybt, dybt betænkelig", udtalte han (Steensbeck og Cordsen, 2003). Efter hans vurdering er det sandsynligt, at den første forsvarer, som støder på brugen af civile agenter eller hemmeligholdelse af materiale, vil forsøge at fă sagen helt til Højesteret som principsag. "Og jeg kan ikke forestille mig, at sådan en sag ikke vil komme til Højesteret. Og den vil også kunne indbringes for Den Europæiske Menneskeretsdomstol" (Hjortdal og Benner, 2003).

"Hastværk" og "Kafkaske retsprincipper" var nogle af de ret voldsomme udtryk, tidligere højesteretspræsident Niels Pontoppidan brugte om den nye rockerlov (Pontoppidan, 2003). Han udtalte betænkelighed ved, hvorvidt loven overhovedet stemmer overens med den Europæiske Menneskerettighedskonvention. Siden Pontoppidan gik på pension i 2000, har han ikke blandet sig i den offentlige debat, så disse store ord fra en ellers forsigtig topjurist vakte en vis opsigt. Dommerforeningen opfordrede direkte justitsministeren til at trække lovforslaget tilbage, og for Advokatrådet var der tale om intet mindre end kimen til en forfatningskrise. "Vi er i den situation, at dommerne har advaret", udtalte generalsekretær i Advokatrådet Henrik Rothe. "Så har politikerne sagt: Vi er ligeglade. Og så har dommerne sagt: Så vil vi ikke dømme" (Hjortdal og Benner, 2003).

Blandt de partier, der al denne tale om forfatningskrise og øget risiko for justitsmord til trods alligevel vovede at vedtage rockerloven 4.6.2003, var Dansk Folkeparti. Lidt over fjorten dage senere brugte partiets formand, Pia Kjærsgaard, sin Sankt Hans-tale til et opsigtsvækkende angreb på Højesteret. Hun anklagede med navns nævnelse dommerne i Højesteret - som ugen før havde frifundet politikeren Karen Sunds fra Folkebevægelsen mod EU for ærekrænkelse, selv om hun havde kaldt Kjærsgaards synspunkter for racistiske - for at være ude i et politisk ærinde. "Højesterets dom er hamrende forkert, hamrende uretfærdig og hamrende politisk", sagde Pia Kjærsgaard i sin tale. "Nok tager jeg dommen til efterretning, men jeg nægter at tage den alvorligt."

Kjærsgaards frontalangreb på den dømmende magt er lige så usædvanligt som ledende danske juristers angreb på den lovgivende magt i forbindelse med rockerloven. At høre en fremtrædende politiker angribe højesteretsdommere og at opleve dommere true regering og Folketing med ikke at ville anvende en bestemt lov er noget nyt i dansk sammenhæng. Fremtrædende danske juristers reaktion på rockerloven kan, mener jeg, tolkes som en form for juridisk aktivisme. Og ret beset er Pia Kjærsgaards slet skjulte trussel om ikke at ville tage en højesteretsdom alvorligt, der gik hende imod, vel også netop en respons på en for lederen af Dansk Folkeparti ny og uacceptabel situation: En aktiv og politiserende Højesteret. Vi befinder os i bogstaveligste forstand et eller andet sted mellem ret og politik, og spørgsmålet er, hvorledes vi skal forklare og også forholde os til, at repræsentanter for to forfatningsorganer nægter at tage hinanden alvorligt? 
Jeg har tidligere argumenteret for, at vores demokrati er ved at ændre sig fra et parlamentarisk til et konstitutionelt demokrati (Porsdam, 2002). Vi orienterer os i stigende grad mod retlige fora og gør brug af en rettighedsdiskurs, når vi skal løse konflikter. Om end der her synes at være tale om tendenser, der også kan iagttages hos vore europæiske naboer, og som mange umiddelbart tilskriver EU og det europæiske samarbejde, mener jeg, at den oprindelige inspirationskilde er USA. I det følgende vil jeg først arbejde videre med disse tanker og påvise de amerikanske rødder i den "nye" konstitutionalisme, som jeg derefter sætter over for Hans Kelsens tanker om udviklingen af constitutional review. Derefter vil jeg se på, hvordan disse tanker genfindes i den seneste udvikling i Danmark.

\section{Den "nye" konstitutionalisme}

I bogen Governing With Judges: Constitutional Politics in Europe fremkommer den amerikanske politolog Alec Stone Sweet med den opsigtsvækkende påstand, at "parliamentary supremacy, understood by most students of European politics to be a constitutive principle of European politics, has lost its vitality. After a polite, nostalgic nod across the Channel to Westminster, we can declare it dead" (Sweet, 2000: 1).

Det, som ifølge Stone Sweet har taget det parlamentariske demokratis plads, er det konstitutionelle demokrati. Sagt på en anden måde er europæisk politik blevet judicialiseret. Judicialisering er et udtryk for den proces, hvorved politikere "absorb the behavior norms of constitutional adjudication, and the grammar and vocabulary of constitutional law, into those repertoires of reasoning and action that constitute political agency. In judicialized politics, legal discourse mediates partisan debate and structures the exercise of legislative power" (Sweet, 2000: 203). Som følge af denne judicialisering er retlige processer blevet "sites of policy-making that supplement, and at times rival, the legislature" (Sweet, 2000:199).

Hvordan er det kommet hertil? Hvordan kan det være, at den lovgivende magts suverænitet er blevet stækket i Europa? Forklaringen må, foreslår Stone Sweet, fortrinsvis søges $i$ to forhold, som begge har med Anden Verdenskrig at gøre: For det første behovet for $\mathrm{i}$ kølvandet på de bitre erfaringer med fascismen $\mathrm{i}$ Italien og Tyskland at tæmme den omnipotente stat, og for det andet den større fokusering på og vilje til også retligt og politisk at håndhæve fundamentale rettigheder. Den massive amerikanske tilstedeværelse i Tyskland og Italien efter krigen var med til at sikre bevågenhed om begge disse forhold. For amerikanerne var intet mere naturligt end at opfordre europæerne til også at tænke i checks and balances-baner - altså at underlægge regeringsmagten i hvert enkelt europæisk land demokratisk kontrol ved at opprioritere den enkelte borgers rettigheder vis-a-vis sin regering og ved at oprette en paneuropæisk politisk struktur, $i$ hvilken intet enkelt land kunne få for megen magt. Efterhånden som den demokratiske rekonstruktion af det forarmede Europa skred fremad, vandt konstitutionalismen frem. Og, hævder Stone Sweet, "as an overarching political ideology, or theory of the state, the new constitutionalism faces no serious rival today" (Sweet, 2000: 37).

Når Stone Sweet her taler om den "nye" konstitutionalisme, er det, fordi konstitutionalismen tog sin praktiske begyndelse allerede med den amerikanske og 
den franske revolution i slutningen af det 18. århundrede. Konstitutionalismen er altså et vestligt koncept med rødder i såvel Vesteuropa som Nordamerika. Begrebsmæssigt kan den føres tilbage til John Lockes (1632-1704), Charles Montesquieus (1689-1755) og Jean Jacques Rousseaus (1712-78) teorier. Dens hovedhjornestene er troen på the rule of law, magtadskillelsen mellem de forskellige grene af magtapparatet og menneskerettighederne. De historiske betingelser, under hvilke konstitutionalismen voksede frem i henholdsvis den Nye og den Gamle Verden, var meget forskellige. I USA var der ikke behov for at vælte nogen lokal magtelite - den engelske konge sad langt væk, og der var ikke noget lokalt herskab/aristokrati, man skulle gøre op med. Mest vigtigt var det at forhindre, at nogen enkeltperson, gruppe eller staten fik for megen magt på bekostning af alle andre. Magtadskillelsen (separation of powers) - både internt i regeringen og mellem de enkelte delstater og den føderale regering - og det at forhindre, at staten blandede sig for meget $\mathrm{i}$ hver enkelt borgers liv, blev derfor skrevet ind i den amerikanske forfatning. Artikel VI i den amerikanske forfatning siger ganske klart, at forfatningen er the supreme law of the land, som overtrumfer det, der måtte stå i de enkelte delstaters love og forfatninger. "This provision of the American Constitution, the key to judicial review, has without a doubt been the main reason for the success story of this constitution as paramount law. For many article VI is the key to modern constitutionalism as such" (Ámason, 2001:44). ${ }^{2}$

I Frankrig kunne bourgeoisiet bruge konstitutionelle forholdsregler til at begrænse kongen og hans ministres magt og samtidig øge deres egen indflydelse som folkevalgte repræsentanter i den lovgivende forsamling. Dette var begyndelsen til den kamp om parlamentarisme, som rasede i Europa op igennem det 19. århundrede. "The Americans chose a way which stabilised constitutionalism based on judicial review and checks and balances, whereas the citizens of Western European countries chose a way which brought them towards modern democracy and close to unlimited parliamentarism" (Árnason, 2001: 46).

Efterhånden som de forskellige europæiske konger fik stækket deres magt, og deres kongedømmer blev omdannet til konstitutionelle monarkier, faldt interessen for konstitutionalisme noget i Europa. Tillid til de nationale parlamenter koblet med mistillid til de overvejende konservative domstole gjorde, at domstolskontrol med regeringsmagten blev anset for at være udemokratisk. Det ændrede sig markant efter Anden Verdenskrig. Med den tyske forfatning (Grundgesetz) og etableringen af den vesttyske Forbundsrepublik i 1949 genskabtes interessen for konstitutionalisme i Europa. En af den nye forfatnings nyskabelser var oprettelsen af en forfatningsdomstol, Bundesverfassungsgericht. Ifølge forfatningen er det denne domstols opgave at påse, at tyske institutioner og organer respekterer forfatningens ord. Tyskland nyder i dag stor anseelse som konstitutionel model for andre europæiske lande. Bundesverfassungsgerichts domme læses med stor interesse af andre europæiske jurister, især når disse domme berører fundamentale menneskerettigheder.

Som jeg har været lidt inde på, spillede USA en vigtig rolle under hele etableringen af en demokratisk national regering i Tyskland. Den britiske politiker og nu professor ved Harvard University, Shirley Williams, formulerer det således: 


\begin{abstract}
"The Federal Republic of Germany evolved rapidly into a rights-based democracy, much influenced by the American model. In June 1948 the three Western allies met in London and agreed, despite profound French disquiet, to convene a German constitutional assembly. Less than a year later the constitutional assembly produced a basic constitution, the Grundgesetz. Drafted in part by Carl Joachim Friedrich, a German academic who had emigrated to the United States and become a distinguished professor at Harvard University, the constitution spelled out in detail the fundamental rights of German citizens ....

Germany's Constitutional Court has become as fierce a guardian of these rights as the U.S. Supreme Court has been of the Bill of Rights and has critically influenced the evolution of human rights law in Europe" (Williams, 2000: 81-82).
\end{abstract}

\title{
Hans Kelsen og udviklingen af constitutional review
}

Helt og fuldt tog tyskerne imidlertid ikke den amerikanske model til sig. Konceptet om en forfatningsdomstol er af europæisk - ikke amerikansk - oprindelse. Den første europæiske forfatningsdomstol oprettedes i Østrig allerede i mellemkrigsårene. Det skete under indflydelse af den kendte og respekterede jurist Hans Kelsen, som i øvrigt også var med til at skrive den østrigske forfatning af 1920. Kelsen argumenterede for, at det juridiske systems integritet kun kunne bevares ved at give statsforfatningsretten en særstatus og ved at oprette en særlig jurisdiktion eller domstol, som netop skulle tage sig af forfatningsmæssige spørgsmål. Kelsen var klar over, at den politiske magtelite ikke ville kunne acceptere en prøvelsesret á la den amerikanske. Det fremherskende europæiske syn var (dengang som nu), som Stone Sweet sammenfatter det, at "American-style judicial review, rather than corresponding to a separation of powers, actually establishes a permanent confusion of powers, because it enables the judiciary to participate in the legislative function. In European parlance, to the extent that courts interfere with the legislative function, a 'government of judges' emerges"' (Sweet, 2000: 33).

Kelsens constitutional review var derfor tænkt som et alternativ til den amerikanske judicial review - et alternativ, som på en og samme tid bevarede den europæiske tro på parlamentarisk suverænitet og tillod en vis form for domstolskontrol. ${ }^{3}$ Således foreslog han for eksempel, at forfatningsdomstolen skulle have beføjelse til at tjekke nye lovforslag med henblik på at fastslå mulige forfatningsmæssige svagheder, før lovforslaget kom til afstemning og dermed til offentlighedens kendskab. På denne måde kunne man forhindre den situation i at opstå, at en domstol skulle tage stilling til en lovs konstitutionalitet. Med undtagelse af sit hjemland vandt Kelsen ikke gehør for sine tanker; i de fleste politiske miljøer rundt omkring i Europa var tanken om oprettelsen af en prøvelsesret - hvilken form den så end måtte tage - endnu i mellemkrigstiden en vederstyggelighed. Det var først efter Anden Verdenskrig, at hans tanker igen blev taget op.

Der var imidlertid ét stort problem med den Kelsenske model for constitutional review. Kelsen havde som juridisk positivist ikke megen fidus til naturretlige argumenter om de i mennesket iboende unalienable rights, som for eksempel den amerikanske Uafhængighedserklæring er fuld af. Efter hans vurdering burde forfatningsdomstole ikke befatte sig med de $\mathrm{i}$ forfatningen sikrede rettigheder, for hvis de gjorde det, risikerede de netop at tage lovgivers plads, og så kunne man for alvor begynde at tale om en regering af dommere. På dette ene punkt 
- de fundamentale (menneske)rettigheder - måtte Kelsens model altså revideres. I de nye forfatninger, som så dagens lys i Europa efter Anden Verdenskrig, spiller de fundamentale rettigheder en helt central rolle, og det blev efterhånden forfatningsdomstolenes fornemste opgave at sørge for, at disse rettigheder blev overholdt. De forfatningssikrede rettigheder, som nævnes i de tyske, italienske og spanske forfatninger - og også de rettigheder, som er blevet inkorporeret $i$ den franske forfatning takket være det franske forfatningsråd - er betydeligt mere omfattende end de rettigheder, vi finder i den amerikanske Bill of Rights (de ti første tilføjelser til forfatningen). For eksempel taler den amerikanske forfatning kun om de politiske og civile rettigheder, mens de europæiske nyere forfatninger også har de økonomiske og sociale rettigheder med. Hans Kelsen ville givetvis ikke have bifaldet denne udvikling, som har medført, at "although the constitutional law is viewed as positive law in these [European] countries, parts of that law - rights - express (or codify) natural law" (Sweet, 2000: 40).

Når det gælder kodificeringen af de fundamentale (menneske)rettigheder, har de nationale forfatningsdomstole fået god hjælp af EU's juridiske organ, EF-domstolen, og også af den Europæiske Menneskerettighedsdomstol. Hvad forstnævnte angår, så har den i sag efter sag - altså på bedste common law manér - siden 1960'erne "effectively 'constitutionalized' the European treaty system, thereby constructing the conditions that enable and sustain judicialization. As judicialization has proceeded in the EC, a quasi-federal, rule-of-law polity has emerged in Europe" (Sweet, 2000: 153). Gennem sin case law har Domstolen bl.a. slået fast, at EU-lovgivningen er autonom i forhold til og også "overtrumfer" den nationale lovgivning, og at de nationale dommere - altså de "almindelige" dommere rundt omkring i Europa - derfor kan anvende EU-lovgivningen direkte i deres daglige virke.

\footnotetext{
"In this jurisprudence, the Court has sought to enlist national judges in a working partnership to construct a constitutional, rule of law Community. As the ECJ [European Court of Justice] has imagined this partnership, national judges become agents of the Community order - they become Community judges - whenever they resolve disputes govemed by EC law. The Court obliges the national judge to uphold the supremacy of EC law... and empowers her...to interpret national rules so that these rules will conform to EC law, and to refuse to apply national rules when they do not" (Sweet, 2000: 163-64).
}

På samme måde som EF-domstolen med en meget dynamisk praksis har været med til at give EU-retten en særstatus i hele Europa, har den Europæiske Menneskerettighedsdomstol været med til at give Den europæiske Menneskerettighedskonvention stor udbredelse. "Siden midten af 1970'erne har EMD [den Europæiske Menneskerettighedsdomstol] udviklet en stadig mere omfattende og finmasket praksis," forklarer Jens Elo Rytter.

\footnotetext{
"De nationale domstole har ikke bare respekteret EMD's praksis, men også ladet sig inspirere af den ... EMD's praksis har således stor og stigende betydning for den nationale ret, både direkte gennem de trufne afgørelser og indirekte gennem afsmitningen på den nationale grundrettighedskontrol" (Rytter, 2000: 12).
} 
Det er navnlig siden slutningen af 1980 'erne, at vi har set en mere og mere aktiv anvendelse og fortolkning også i dansk ret af Den europæiske Menneskerettighedskonvention. Faktisk er udviklingen allerede nået så vidt, fortsætter Rytter,

\footnotetext{
"at ingen advokat, dommer, embedsmand eller andre, der beskæftiger sig med for eksempel strafferet, udlændingeret, forvaltningsret, arbejdsret, socialret og familieret i dag kan komme udenom at inddrage individets grundlæggende rettigheder - som disse er fastlagt i EMRK [Den europæiske Menneskerettighedskonvention] og grundloven og stadig udbygges $i$ et samspil mellem EMD og danske domstole" (Rytter, 2000: 14).
}

Resultatet er, at det i dag i Europa i praksis ikke længere kun er forfatningsdomstolenes dommere, som udøver constitutional review. Også de "almindelige" dommere er af EF-domstolen og den Europæiske Menneskerettighedsdomstol blevet udstyret med prøvelsesretlige eller -lignende beføjelser $-\mathrm{i}$ al fald når EU-retten og/eller menneskerettighederne er involveret. Jeg vil derfor her vove den påstand, at den skelnen, der i sin tid blev lavet mellem amerikansk judicial review og europæisk constitutional review gradvist er ved at blive udvisket. I den amerikanske konstitutionelle model er det sådan, at "any judge of any court, in any case, at any time, at the behest of any litigating party, has the power to declare a law unconstitutional" (Sweet, 2000: 32). Er det ikke her, vi også i Europa er ved at være efterhånden? Jo mere rights talk, vi har fået i Europa, og jo mere "almindelige" EU-borgere gør brug af den juridiske del af EU-systemet (EF-domstolen), men også den Europæiske Menneskerettighedsdomstol, jo mere involveres også "almindelige" dommere - og andre jurister - $\mathrm{i}$ beskyttelsen af de grundlæggende rettigheder. Bag den påvirkning, vi her i Danmark modtager gennem EU og det europæiske projekt, er der altså en god portion amerikansk indflydelse. En anden måde at sige det på, er, at det er den amerikanske konstitutionelle model med judicial review på alle niveauer, der synes at vinde frem på bekostning af den europæiske constitutional review model.

\section{Den seneste danske udvikling \\ Domstolene}

Det var først med Tvinddommen i 1999, at den danske Højesteret besluttede sig for at tilnærme sig den mere aktivistiske stil, som har været kendetegnende for den europæiske udvikling siden Anden Verdenskrig. Der havde været tilløb op gennem det 20. århundrede, men det var først i slutningen af $1990^{\prime} e r n e$, at slridtet blev taget fuldt ud. Hvor stor en vilje til juridisk aktivisme vi i fremtiden vil se hos danske højesteretsdommere, er det naturligvis svært at spå om. Der er imidlertid en række forskellige hændelser og tiltag, der klart viser, at den danske juridiske profession som helhed er ved at flytte sig. Jeg skal her pege på et par enkelte.

Der har de senere år været en god del opmærksomhed omkring domstolene og dommerstanden i al almindelighed. Det har for eksempel været genstand for diskussion, hvad dommere kan tillade sig at lave uden for deres regulære arbejdstid, hvorvidt retskredsene skal gøres større, samt hvem der skal udnævne dommere. 
Med hensyn til sidstnæunte er det pr. 1. juli 1999 ikke længere Justitsministeriet, men et særligt Domstolsudnævnelsesråd under Domstolsstyrelsen, der indstiller til udnævnelse af dommere. Dette råd består af tre dommere (en højesterets-, en lands- og en byretsdommer), en advokat og to repræsentanter for offentligheden. Det lukkede karrieresystem har ligeledes været diskuteret. I den betænkning, der lå til grund for flere af disse ændringer (Domstolsudvalgets betcenkning, nr. 1319, 1996) peges der for eksempel på, at der må gøres noget for at sikre et mere forskelligartet rekrutteringsmønster til domstolene. Dersom domstolene skal have en større retsskabende funktion - og det mener arkitekterne bag Betcenkning 1996 vil være ønskværdigt - kræver det, at dommerkorpset bliver sammensat på en sådan måde, at flere forskellige erfaringsgrundlag bliver tilgodeset. For ikke blot at få folk, der er ukritiske over for statsmagten, vil det for eksempel være fint, om flere advokater kunne blive interesserede i at blive dommere.

To af de tre sidst udnævnte højesteretsdommere kommer faktisk fra advokatstanden - nemlig Thomas Rørdam og Jon Stokholm. Førstnævnte tog som ung jurist en LL.M-grad ved Stanford University, og Jon Stokholm har fungeret som advokat i et amerikansk advokatfirma. Om det var i USA, de begge lærte at omgås medierne, kan vi ikke vide. Men vi har de senere år - lige indtil de begyndte at få deres daglige gang i Højesteret - ofte hørt og set begge d'herrer i radio og på fjernsyn. Det var forskellige interesser, de varetog og talte på vegne af, men pointen her er, at hverken Rørdam eller Stokholm umiddelbart passer særlig godt ind $\mathrm{i}$ den embedsmandskultur, de fleste forbinder med Højesteret.

Det er i denne sammenhæng lige værd at bemærke, at en væsentlig grund til den "judicialisering", som kendetegner USA, netop er de mange advokater, der udnævnes til dommere. Det hævder i al fald den amerikanske juraprofessor Martin Shapiro. Shapiro konstaterer kort og kontant, at "if any nation is the peculiar home of the expansion of judicial power, it is the United States." Dette er et stort og mangesidet fænomen, som er et resultat af mange forskellige faktorer, men den forste af disse, han beskæftiger sig indgående med, er udnævnelsen af advokater til dommere.

\footnotetext{
"The distinctive American mode of selecting judges from this broadly recruited, highly politicized and overwhelmingly private-practice bar may be the crucial cause of judicialization ... The American judiciary is recruited very largely from among middle-aged, successful private practitioners who have been deeply and directly involved in private enterprise, typically have little or no experience in government, and typically have built some substantial portion of their success on representing interests heavily regulated by government ... Thus they have both the knowledge needed and the inclination to intervene in affairs of state to a far greater degree than do European judges" (Shapiro, 1995: 44-46).
}

\section{Andringer $i$ advokatbranchen}

Den igangværende retskredsreform i domstolene kan meget vel tænkes at ville få en afledt effekt på advokatbranchen - nærmere betegnet på koncentrationen af advokatvirksomheder. Reformen vil formentlig medføre, at antallet af byretter og politikredse vil blive reduceret, og denne modernisering af domstolenes struktur vil sandsynligvis befordre den nuværende tendens mod færre og større advokat- 
firmaer. For at klare sig i fremtidens konkurrence - med bl.a. ejendomsmæglerne, som efter at advokaternes monopol på skødeskrivning blev ophævet ved lov i slutningen af 1990'erne, er begyndt at være deres kunder behjælpelige med både prisforhandling, finansieringsvalg og selve udfærdigelsen af skøder, med bankerne, som står på spring for at sikre sig en del af advokaternes indtjening på handel med fast ejendom, samt med revisorerne, som har bredt deres arbejdsfelt ud til også at omfatte en del jura - må advokatfirmaer organisere sig i større og mere slagkraftige enheder med en dybere specialisering. "Jeg tror ikke, vi făr flere af de helt store kontorer fremover," udtalte daværende formand for Advokatrådet Jon Stokholm til DJØFbladet i marts 2002. "Jeg tror snarere, at den retsreform, man taler om i øjeblikket, vil skabe nogle store regionale enheder, og vi vil se flere fusioner mellem provinsbyernes kontorer - også uden for København og Århus" (Santesson, 2002: 10).

Større enheder inden for advokatbranchen kan måske også afhjælpe et yderligere problem. I løbet af de næste femten år vil godt halvdelen af advokaterne gå på pension, ligesom tilgangen af nye, unge jurister skønnes at ville falde noget. Dette sidste skyldes dels, at den samlede befolkningstilvækst bliver mindre og dels, at især kvindelige jurister finder det vanskeligt at forene et familieliv med de lange arbejdstider, de har som advokater. Flere af dem deponerer derfor deres bestalling i Justitsministeriet og făr i stedet job i private virksomheder eller i det offentlige. Her kan tendensen mod større advokatfirmaer komme til at spille en stor rolle. Det at opnå en vis kritisk størrelse for et advokatfirma kan gøre det attraktivt for nyuddannede jurister at søge ind i firmaet. De nye fuldmægtige ved, at de skal alle specialerne igennem - altså at de vil kunne opnå en god, alsidig uddannelse - før de vælger speciale inden for det felt, de er bedst til.

Når det gælder om at lokke nye fuldmægtige til, kan også efteruddannelse spille en stor rolle. En større satsning på karriere og på uddannelse såvel i som uden for Danmark virker tiltrækkende på nyuddannede jurister. Med hensyn til efteruddannelse i udlandet, så er USA i dag et af de mest attraktive steder at tage hen for unge, ambitiøse advokatfuldmægtige. Efter et års studier ved et amerikansk universitet kan man opnå en såkaldt Master of Laws grad (LL.M), en grad som giver udenlandske jurister en indføring i det amerikanske retssystem og amerikansk jura. Tager man derefter en bar exam i en af delstaterne, kan man få stilling i et advokatfirma og høste værdifulde praktiske erfaringer, som man kan tage med sig hjem til Danmark bagefter. Der findes ingen officielle tal på, hvor mange danske jurister, der rent faktisk tager til USA, men der er almindelig enighed inden for advokatbranchen om, at tallet er stigende. Opnåelsen af den amerikanske LL.M.grad er, skriver Helle Blomquist, blevet et mere værdifuldt aktiv for de store firmaer end opnåelsen af møderet for Højesteret (Blomquist, 2000: 186).

En af de ting, danske og andre europæiske jurister konfronteres med ved amerikanske low schools er den allerede omtalte stærke rettighedskultur. Den amerikanske tro på juraen som kur for de fleste af samfundets problemer og vilje til at retliggøre alt fra overtagelser i forretningslivet til præsidentvalg afstedkommer i starten nogen undren. Flere af de europæiske jurister vil efter et eller flere år i USA dog have fået revideret deres syn ikke blot på forholdet mellem jura, 
erhvervsliv og politik, men også på, hvad jura, domstole og jurister kan - og bør - udrette.

\section{Nye arbejdsområder for juristerne}

Samtidig med, at vi har set en ændring af dansk demokrati over i retning af et demokrati med konstitutionalisme, har vi også set en stigende tendens til, at danskerne opfatter deres velfærd som en rettighed mere end som et tilbud eller en gave, de skal være taknemmelige for at opnå. Rettighedstankegangen vinder frem, og den ytrer sig rent konkret i en ny og "anderledes" slags retssager. Jeg tænker her især på retssager inden for det sociale område - retssager, som omhandler sociale og økonomiske rettigheder. Undersøgelser af forvaltningen er for eksempel blevet et nyt arbejdsområde for advokaterne. Det er almindelig kendt, at der sker mange fejl i forbindelse med administrationen af lovregler. Et stigende antal borgere ønsker derfor at få prøvet forvaltningsafgørelser omhandlende eksempelvis miljøet eller sociale rettigheder ved domstolene, og det øger behovet for juridisk bistand.

Vi har ydermere set folk lægge sag an mod deres lokale kommune for ikke at leve op til de love, der er vedtaget på Christiansborg; vi har set flere erstatningssager for skader påført $i$ arbejds medfør, og vi har set borgere lægge sag an mod staten, selv om de ikke selv umiddelbart er berørte parter i sagen. Ifølge det traditionelle søgsmålsbegreb kan vigtige offentligretlige spørgsmål, som ikke konkret berører sagsøgeren, ikke indbringes for domstolene. Højesteret har imidlertid i en række sager de senere år anerkendt behovet for domstolsprøvelse af væsentlige offentligretlige spørgsmål og derfor omfortolket kravet om "retlig interesse" i sagen. Det er sket i erkendelse af, at der findes retsområder, hvor der står meget generelle og almene samfundsinteresser på spil, og hvor det derfor kan være vanskeligt at udpege en enkelt person som den konkret berørte. Som forklaringsfaktor for denne tendens hen imod udvidet søgsmålsret peger Pernille Boye Koch i sit bidrag til Staten i forandring på "anerkendelsen af domstolene som en vigtig aktor ved løsningen af voesentlige samfundsspørgsmål." Denne skal ses i sammenhæng med konstitutionalismens stadig større udbredelse.

\footnotetext{
"Ikke blot i omverdenen men også ved domstolsinstitutionen selv er det således accepteret, at de danske domstole vil f̊̊ stadig større betydning som selvstændig samfundsaktør. Og det er sandsynligvis sket i erkendelse af, at domstolene i en stadig mere rettighedsbaseret kultur udgør borgernes væsentligste bolværk mod magtmisbrug"'(Koch, 2001: 208).
}

Godt i tråd hermed falder nogle af de forsøg, advokater har udført for at få visse af de i grundloven nævnte sociale rettigheder, som tidligere blev opfattet som politiske programerklæringer, anerkendt som konkrete rettigheder. Tag for eksempel grundlovens $\S 75$, som taler om, at der "til fremme for almenvellet" bør gives "enhver arbejdsduelig borger mulighed for at arbejde på vilkår, der betrygger hans tilværelse." Af stk. 2 fremgår det endvidere, at "den, der ikke selv kan ernære sig eller sine, og hvis forsørgelse ikke påhviler nogen anden, er berettiget til hjælp af det offentlige." Efterhånden som der tales mere og mere om, at de 
sociale, økonomiske og kulturelle rettigheder bør anerkendes på lige fod med de politiske og borgerlige rettigheder, er det en helt naturlig udvikling for en dansk advokat at ville tage lovgiver på ordet, så at sige - at afprøve, hvor langt domstolene er villige til at gå med hensyn til en konkret fortolkning af for eksempel grundlovens $§ 75$. Og det er lige præcis, hvad advokat Christian Harlang er i færd med. Han er involveret i en sag, som omhandler kontanthjælpen til arbejdsløse og vil have Højesteret til at tage stilling til, om det er grundlovsstridigt at standse kontanthjælpen til arbejdsløse, der ikke vil aktiveres. Dette er blot en refleksion af den konkrete betydning for den enkelte dansker, grundloven synes at have fået som et sæt af egentlige retsnonner, der kan håndhæves i domstolssystemet.

Med den nye europæiske forfatning, som i disse år er under udarbejdelse, vil EU-retten komme til at spille en endnu større rolle i den enkelte europæers liv. Det samme vil menneskerettighederne, idet det Europæiske Charter om fundamentale rettigheder, bliver skrevet mere eller mindre direkte ind $\mathrm{i}$ forfatningen. Det Europæiske Råd besluttede i juni 1999, at der for EU skulle udarbejdes et charter, der skulle omfatte og formulere de grundlæggende menneskerettigheder for EU. Det Europæiske Charter om fundamentale rettigheder blev godkendt på et møde i Nice i december 2000, og det udmærker sig blandt andet ved i en og samme tekst at kombinere de civile og politiske rettigheder med de økonomiske og sociale rettigheder. Hermed cementeres opfattelsen af menneskerettighederne som lige, udelelige, indbyrdes forbundne og indbyrdes afhængige. Sociale og økonomiske rettigheder bliver legale rettigheder - rettigheder, man kan gå til domstolene med. Den økonomiske og sociale retning, samfundet vælger at gå, vil ikke længere udelukkende være et politisk projekt; det vil også være et retligt projekt. Og når vores velfærd således kommer på rettigheder, vil det ikke blive nemmere at se, hvor grænsen går mellem ret og politik!

Jeg vil slutte af med endnu en type "anderledes" sager, vi har oplevet i Danmark inden for de senere år. Da en nydansk kvinde i 1999 mødte op som erhvervspraktikant hos Magasin med tørklæde om hovedet, blev hun afvist. Dette skete under henvisning til forretningens almindelige beklædningsvejledning. Kvinden lagde sag an mod Magasin, og Østre Landsret fandt i august 2000, at Magasins afvisning var udtryk for indirekte diskrimination. Kvinden blev tilkendt en erstatning på 10.000 kr., og Magasin måtte ændre sin personalepolitik. Der var et vist element af ytringsfrihed over "Tørklædesagen," som denne sag efterfølgende blev kaldt, men den indeholdt også et solidt element af identitetspolitik. Sammenkædningen her af værdier, mindretalsbeskyttelse og rettigheder er interessant. Den er noget nyt i dansk sammenhæng - men bestemt ikke i amerikansk.

Vi er i Danmark godt på vej til at få en rettighedsbaseret kultur, som minder en hel del om den amerikanske. Dette med at formulere et politisk, socialt eller kulturelt budskab ved hjælp af en rettighedsdiskurs er noget, vi vil se meget mere til de kommende år. Vi vil få flere sager som Tørklædesagen - sager, som har et multikulturelt, identitetspolitisk præg - og vi vil se vore domstole blive det sted, hvor man mødes for at løse alle de mange konflikter, der uvægerligt vil opstå i et multikulturelt samfund, hvor der ikke er enighed om normer og værdier. 


\section{Konklusion}

Da den østrigske retsfilosof Hans Kelsen i 1920'erne begyndte at plædere for indførelsen af constitutional review, insisterede han på, at dommerne burde overlade sager, som omhandlede borgernes fundamentale rettigheder, til de folkevalgte politikere. Når og hvis dommerne i disse nye forfatningsdomstole fik jurisdiktion over sådanne sager, ville de langsomt, men sikkert fortrænge lovgiver. Kelsen's prognose var korrekt, og udviklingen i EU burde derfor ikke være kommet bag på os. "If Europeans wish to have judicially enforceable rights then they must accept that constitutional judges will fully participate in the legislative function," siger Stone Sweet. "It follows that the legitimacy of constitutional rule-making is ultimately tied to the legitimacy of rights." Spørgsmålet om, hvorvidt det, dommere - såvel 'forfatningsdommere' som 'almindelige' dommere - laver, når de afgør sager, der har med borgernes fundamentale rettigheder at gøre, er politisk eller ej, er derfor meningsløst. Det spørgsmål, vi europæere i stedet burde stille os selv og hinanden lyder sådan her:

\footnotetext{
"We get closer to reality if we go beyond the question of whether constitutional judges legislate when they protect rights, and ask instead: do constitutional judges, in fact, protect rights better than governments and parliaments do, or would do in the absence of constitutional review?" (Sweet, 2000: 151).
}

Som Stone Sweet ser det, burde vi svare bekræftende på dette spørgsmål. Nu er han jo også amerikaner og derfor vant til et samfund, i hvilket domstolene er vigtige samfundsaktører. For de fleste danskere er det ikke umiddelbart indlysende, at øget juridisk aktivisme vil have en gunstig indvirkning på det danske demokrati og forfatningsliv. Det er store og vigtige ting, der står på spil her. Stone Sweet har ret $\mathrm{i}$, at den diskussion, vi bør tage, drejer sig om, hvorvidt det skal være Folketinget eller domstolene med Højesteret i spidsen, som skal fortolke Grundloven, Den europæiske Menneskerettighedskonvention og den nye EU-forfatning. Skal vi have demokrati uden eller demokrati med konstitutionalisme? Hvem er bedst egnet til at sikre borgernes fundamentale rettigheder - politikerne eller domstolene? Har Michael Ignatieff ret $i$, at demokrati uden konstitutionalisme er etnisk flertalstyranni, og at den eneste måde at "indtænke" minoritetsrettigheder på er at støtte udviklingen fra demokrati uden til demokrati med konstitutionalisme?

\section{Noter}

1. Pia Kjærsgaard i Christine Cordsen, "Pia K. angriber Højesteret," Politiken, 1. sektion, p. 5, 24.6.2003. To dage senere stod Kjærsgaards tale at læse i Politiken: "Højesteretsdom om racisme er politisk" ("Injurier"), 2. sektion, p. 7. Samme dag citerede Politiken dommerforeningens formand, Henrik Linde, for at sige, at Kjærsgaards angreb på Højesteret er "meget uheldigt. Det må vi på det kraftigste tage afstand fra" (Henrik Kaufholz, "Dommere vrede på Pia K.," Politiken, 26.6.2003, 1. sektion).

2. Mingennemgang af det historiske forløb af den modeme konstitutionalisme bygger på Ámasons fremragende artikel (2001). 
3. Constitutional review er det begreb, Alec Stone Sweet bruger. Dette og det følgende afsnit bygger på Governing With Judges.

\section{Litteratur}

Ámason, Áugust Thór (2001). “Constitutionalism: Popular Legitimacy of the State?”, pp. $29-78$ in Martin Scheinin (ed.), Welfare State and Constitutionalism - Nordic Perspectives, Copenhagen: Nordic Council of Ministers.

Blomquist, Helle (2000). Lawyers' Ethics: The Social Construction of Lawyers' Professionalism. Danish Practicing Lawyers And Some Pre-Conditions for Their Ethics, Copenhagen: DJØF Publishing.

Hjortdal, Marie og Torben Benner (2003). "Næste stop: Højesteret", Politiken, 5.6., 1. sektion, p. 8.

Ignatieff, Michael (2001). Human Rigths as Politics and Idolatry, Princeton, NJ: Princeton University Press.

Koch, Pernille Boye (2001). "At sagsøge staten - på vej væk fra det traditionelle søgsmålskrav?", pp. 201-213 i Hanne Petersen, Henning Koch og Pernille Boye Koch (red.), Staten i forandring, København: Jurist- og Økonomforbundets Forlag.

Nielsen, Gorm Toftegaard (2001). "Domstolene som den tredje statsmagt", pp. 147-80 i Gorm Toftegaard Nielsen 0.a. (red.), Parlamentarismen: Hvem tog magten?, Arhus: Aarhus Universitetsforlag.

Pontoppidan, Niels (2003). "Rockerbekæmpelse med kafkaske retsprincipper", Politiken, 15.5., 2. sektion, p. 8.

Porsdam, Helle (2002). Fra pax americana til lex americana? En diskussion af dansk retliggørelse som en påvirkning fra USA, Århus: Magtudredningen.

Rytter, Jens Elo (2000). "Rettighedsevolutionen i dansk ret", Lov og Ret, nr. 4, pp. 10-14.

Santesson, Tine (2002). "Advokatbranchen under forandring", DJØFbladet, nr. 5, 1.3., pp. 10-11. Shapiro, Martin (1995). "The United States", pp. 43-66 in C. Neal Tate and Torbjörn Vallinder, The Global Expansion of Judicial Power, New York: New York University Press.

Smith, Eva (2003). "Der var engang en retsstat", Politiken, 7.5., 2. sektion, p. 7.

Steensbeck, Bjarne og Christine Cordsen (2003). "Dommer trodser rockerlov", Politiken, 17.5., 1. sektion, p. 1.

Sweet, Alec Stone (2000). Governing With Judges: Constitutional Politics in Europe, Oxford: Oxford University Press.

Williams, Shirley (2000). "Human Rights in Europe", pp. 77-109 in Samantha Power and Graham Allison (eds.), Realizing Human Rights: Moving From Inspiration to Impact, New York: St. Martin's Press. 